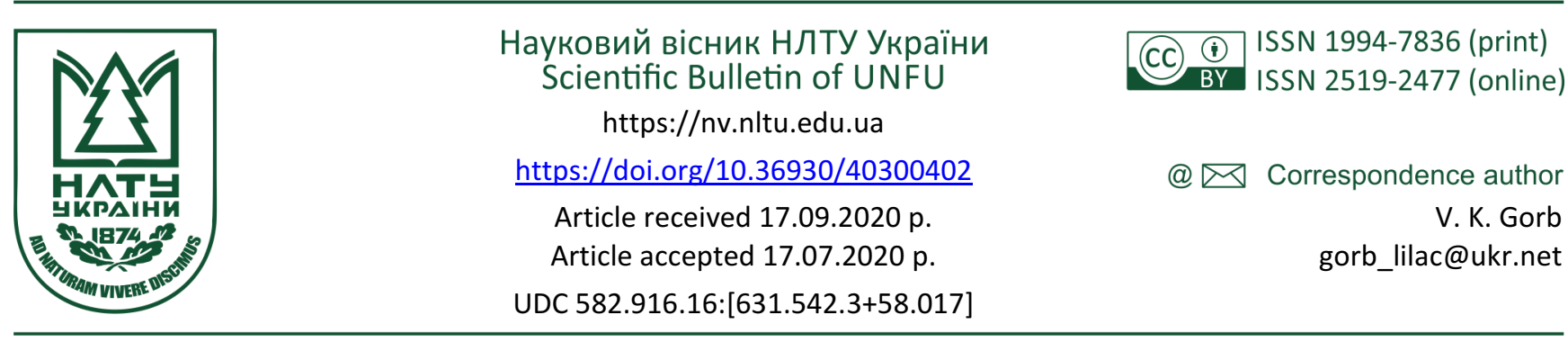

В. К. Горб, Ю. О. Клименко, Н. І. Довгалюк

Національний ботанічний сад ім. М. М. Гришка, НАН Украйни, м. Київ, Украӥна

\title{
ВПЛИВ СИСТЕМИ ДОГЛЯДУ ЗА КРОНОЮ НА ДЕКОРАТИВНІСТЬ І ДОВГОВІЧНІСТЬ РОСЛИН СОРТIВ SYRINGA VULGARIS L.
}

Досліджено вплив способів обрізування крони рослин Syringa vulgaris L. на їхню декоративність і довговічність. Встановлено, що досягти найкращого результату можна тільки за регулярного догляду за кроною. Спонукає до цього, щонайперше, дихотомічне (несправжнє) гілкування, за яким кожна однорічна гілка продукує навесні два пагони з верхівкової пари бруньок та ще кілька - з бруньок, що розташовані нижче по осі цієї гілки. Отже, щороку загальна їхня кількість щонайменше потроюється. Коренева система не зможе за цей час збільшити в таких обсягах свою масу і фізіологічну активність, що корелятивно спричиняє значне зменшення розмірів пагонів і суцвіть. Якщо догляд був нерегулярний або відсутній, виникає потреба інтенсивного прорідження або кардинального омолодження крони. Доведено, що цими заходами можна поліпшити декоративність рослин, але на довговічність вони вплинуть негативно. Зумовлює це дві причини. Перша - запобігання ран внаслідок видалення гілок на кільце. Встановлено, що навіть 1,5-2,0-сантиметрові зрізи на стовбурі чи скелетних гілках ніколи не загояться, а за 10-15 років їхня деревина струхліє, утворивши порожнину. Деревина великих ран руйнується швидше, що призводить до виникнення дупел та повільного відмирання всієї рослини. Другою причиною вкорочення довговічності є раптово порушений функціональний корелятивний коренево-листковий зв'язок, що є наслідком різкого зменшення в омолодженій рослині надземної частини. Спочатку це призведе до сповільнення фотосинтезу (крона майже відсутня), а потім, корелятивно, й до затухання кореневого синтезу: через мізерне надходження асимілятів до коренів. Унаслідок цього загальна маса фізіологічно активної частини кореневої системи теж значно зменшиться, що негативно вплине на довговічність рослини загалом. Декоративність кущів через це з року в рік погіршується. Також встановлено, що до обрізування крони змушує й загушена посадка бузків. Для відновлення її декоративності спочатку варто видалити кволі рослини, а в решти - знизити крону приблизно на третину аби наблизити ії до кореневої системи, що забезпечить рослинам фізичну витривалість та дещо внормує в них функціональний коренево-листковий зв'язок. Здійснити цей захід треба якомога раніше в часовому вимірі, бо, окрім згаданого, рослини почнуть страждати й від хвороб. Потужні гілки потрібно вкорочувати, а не вирізати на кільце, аби не нанести стовбурам і гілкам першого порядку великих ран. За такого підходу до обрізування крони бузки будуть декоративними й здебільшого випадків - довговічними.

Ключові слова: Syringa vulgaris L.; формування крони; декоративність; довговічність.

\section{Вступ}

Упродовж останніх десятиліть в Свропі дедалі частіше вводять в озеленення види роду Syringa L. Особливий попит припадає на бузок звичайний (S. vulgaris), як найдекоративніший серед них. 3 його рослин створюють монокультурні сади, алеї, високі живоплоти, групи на газоні тощо. Аби бузок виглядав декоративно, садівники поліпшують насамперед грунтові умови, менше дбаючи про стан надземної частини. Як наслідок, з роками, крона поступово перегущується, старіє, стає малодекоративною. Аби покращити фізіологічний і зовнішній стан іï, виникає потреба в кардинальному омолодженні: усі дрібні гілки зрізати на рівні грунту, а найтовстіші - на незначній висоті від нього. Досвід свідчить, що цей захід тільки тимчасово покращить естетичний вигляд рослини, але в подальшому негативно вплине на ії фізіологічний стан. Саме через це виникла потреба підібрати методи, які давали б змогу за найменшого втручання в систему надземних органів рослини, максимально поліпшити іiі декоративність і позитивно вплинути на її довговічність.

Аналіз останніх досліджень та публікацій. Наукових робіт $з$ догляду за кроною бузків немає. Тільки в деяких довідниках [4] і популярних виданнях [2] зазначено, що з віком рослини S. vulgaris варто омолоджувати аби їхні суцвіття гарно виглядали й їх було зручно розглядати. Для цього пропонують видаляти пошкоджені й дрібні застарілі гілки, а іноді - й усі центральні стовбури [2]. Дещо пізніше було сформульовано стислі рекомендації [1] інтенсивного омолодження багаторічних кущів. Про негативну післядію на рослини цього методу нічого не зазначено. Отже, він має бути переос-

\section{Інформація про авторів:}

Горб Василь Кузьмович, канд. біол. наук, ст. наук. співробітник, відділ дендрологіï. Email: gorb_lilac@ukr.net; https://orsid.org/0000-0002-3046-9702

Клименко Юрій Олександрович, д-р с.-г. наук, ст. наук. співробітник, завідувач відділу дендрології. Email: klimenco109@ukr.net; https://orsid.org/0000-0003-4695-9527

Довгалюк Наталія Іванівна, пров. інженер, відділ дендрологіï. Email: nata_0305@ukr.net; https://orsid.org/0000-0001-5951-8857

Цитування за ДСтУ: Горб В. К., Клименко Ю. О., Довгалюк Н. І. Вплив системи догляду за кроною на декоративність і довговічність рослин сортів Syringa vulgaris L. Науковий вісник НЛтУ України. 2020, т. 30, № 4. С. 14-18.

Citation APA: Gorb, V. K., Klymenko, Yu. O., \& Dovhaliuk, N. I. (2020). Influence of the crown care system on the decorativeness and longevity of plants of Syringa vulgaris L. varieties. Scientific Bulletin of UNFU, 30(4), 14-18. https://doi.org/10.36930/40300402 
мисленим з погляду його негативного впливу, передусім на довговічність рослин.

Об'єкт дослідження - різновікові рослини сортів S. vulgaris.

Предмет дослідження - методи формування й обрізування крони різновікових рослин сортів $S$. vulgaris.

Мета дослідження - опрацювати систему догляду за кроною рослин сортів S. vulgaris. для утримання їх у декоративному стані та підтримання їхньої довговічності.

Для досягнення зазначеної мети потрібно виконати таке основне завдання дослідження - підібрати методи і засоби для ефективного догляду за кроною $S$. vulgaris.

Наукова новизна отриманих результатів дослідження полягає в тому, що встановлено причину, за якої виникає потреба систематичного догляду за кроною S. vulgaris в умовах культури. Підібрано методи, використання яких поліпшить декоративність крони і позитивно вплине на довговічність рослини загалом.

Практична значущість результатів дослідження полягає в тому, що у разі своєчасного використання запропонованих методів догляду за надземною частиною рослин $S$. vulgaris вони будуть декоративними й довговічними.

Матеріали та методи дослідження. Дослідження виконано впродовж 2000-2019 рр. у Сирингарії Національного ботанічного саду ім. М. М. Гришка НАН України. Для вивчення залучено різновікові рослини S. vulgaris та її сорти, які росли на ідентичному агрофоні. Використано морфологічний та польовий методи.

\section{Результати дослідження та їх обговорення}

Рослини S. vulgaris не особливо вибагливі до грунтового живлення, тому, зростаючи вільно, можуть мати задовільний декоративний вигляд навіть без особливого догляду за кроною. Та все ж, враховуючи їхню потенційно високу декоративність, бузководи намагаються найповніше розкрити ії різними способами, використовуючи й інтенсивні методи догляду за кроною, передусім - обрізування. При цьому досить часто не враховують впливу цього заходу на тривалість життя рослин. Аби з'ясувати це, варто порівняти фізіологічний стан, декоративність і довговічність тих рослин, які майже дико ростуть на схилах старих ландшафтних парків, біля сільських хат, на освітлених узліссях з тими рослинами, які знаходяться в умовах систематичного догляду.

Перші, за більш-менш сприятливого агрофону та вільного розташування просто неба, можуть рости на одному місці на теренах Полісся, Лісостепу та Степу України сотню й більше років, бо на заміну старим стовбурам куща виростають нові $з$ прикореневої зони або зі столонів. Цей процес проходить уповільнено, тому надземна частина завжди залишається майже цілісною, а природно узгоджений у ній функціональний корелятивний коренево-листковий зв'язок практично не порушується. Тому рослини ростуть й розвиваються ритмічно, без стресів. Квітують майже щорічно, хоча не рясно й не завжди всією кроною.

В урбанізованому середовищі - у ботанічних садах, дендропарках, міських парках і скверах та на присадибних ділянках бузки мають бути високодекоративними. Саме тому догляд за надземною частиною здійснюють майже систематично, аби вони виглядали естетично не тільки в період квітування, а й після його завершення: мали б ошатну пропорційно розвинену крону. Досягти цього можна тільки за умови щорічного обрізування крони, яке зумовлює, насамперед, дихотомічне (несправжнє) гілкування, за якого кожна однорічна гілка цього виду продукує навесні два пагони 3 верхівкової пари бруньок та ще кілька - із бруньок, що розташовані нижче по осі цієї гілки. Отже, щороку загальна їхня кількість щонайменше потроюється. Коренева система не може щорічно збільшувати свою масу і фізіологічну активність в таких обсягах, що корелятивно призводить до значного зменшення метричних розмірів пагонів $\mathrm{i}$, головне, - суцвіть. Декоративність кущів через це з року в рік погіршується. Отже, обрізувати крону необхідно, але з урахуванням біологічних особливостей рослин, тобто так, щоб, перше: у процесі проведення цього заходу якнайменше були порушені функціональні корелятивні коренево-листкові зв'язки, й друге - щоб рослині найменше було завдано ран. Дотримуючись цього правила покращимо не тільки декоративність рослин, а й позитивно вплинемо на їхню довговічність.

Наші багаторічні спостереження свідчать про надто негативну реакцію рослин на завдані їй рани під час формування крони, а з роками - і під час систематичного іiі обрізування. Так, навіть 1,5-2,0-сантиметрові рани у рослин $S$. vulgaris практично не загояться й впродовж десятків років. Проте найгіршим $є$ те, що через їхню поверхню до деревини проникне патогенна мікрофлора, яка за 15-20 років перетворить ії в порохню. Активність цього процесу прямо залежить від розмірів рани: чим вони більші, тим процес руйнування деревини відбуватиметься швидше.

Враховуючи це, сформувати крону саджанців $S$. vulgaris треба не пізніше 2-3-річного віку. Якщо це буде кущ, то варто залишити 4-5 пагони, які будуть спрямовані в усі боки від його центру. В наступні роки варто видаляти всі однорічні гілочки, які ростимуть в середину куща. В подальшому можна допускати ії заповнення, але без загущення. За такої умови не доведеться видаляти товсті гілки, тому зрізи матимуть мінімальний діаметр, які впродовж декількох років закриє калюс. Крону одностовбурних (штамбових) рослин потрібно закласти теж в 2-3-річному віці. Залишити варто 34 скелетні гілки, які, як і стосовно кущів, мають бути спрямовані в різні боки від центру крони. В подальшому також не варто допускати загущення ії центральної частини. Іноді може статись так, що якусь зі скелетних гілок першого порядку вчасно не видалили й вона стала перевантажувати крону. Аби не завдати значної рани стовбурові рослини вирізати ії на кільце не варто: треба тільки вкоротити по довжині на третину.

Загальний обсяг гілок, яких бажано позбутись навесні, залежить від віку рослини й агрофону ділянки. Молоді саджанці досить активно реагують навіть на незначне зменшення крони, тому видаляти варто тільки зайві гілки та вкоротити ті поодинокі, які стали домінувати над кроною. Інтенсивнішим обрізуванням спровокуємо появу довгоростучих вертикально спрямованих жирових пагонів-вовчків, які швидко переповнять надземну частину рослини. Зі старіших кущів варто щороку видаляти всі зайві, невеликі за розміром гілки, сумарна маса яких має бути в межах 10-15\% від усієї. Інтенсивніше втручання в систему надземних органів рослини надто порушить в ній функціональний корелятивний коренево-листковий зв'язок. Декоратив- 
ність рослини при цьому може навіть тимчасово покращитись, але на ії̈ довговічність вплине негативно [3].

Ландшафтні архітектори, особливо початківці, проектуючи якесь зелене влаштування, не завжди звертають належну увагу на біологічні особливості тих деревних і кущових рослин, які вони залучають до свого об'єкта. Насамперед це стосується такої ознаки, як світлолюбність, нехтування якою призводить до неправильного вибору густоти садіння рослин у групах. Найчастіше їх розміщують значно щільніше, аніж це потрібно. Спонукає до цього, напевно, бажання проектанта одразу побачити свій об'єкт у завершеному вигляді: заповненим рослинами, тобто - декоративним. Але негативні наслідки такого підходу проявляться вже через кілька років: рослини зімкнувшись кронами, потягнуться вгору, а це значно погіршить їхній фізіологічний і декоративний стани. Стосується це й рослин $S$. vulgaris, як надто світлолюбних. У разі близького розташування їх у групі, їхня крона стрімко спрямовується вгору, суцвіття подрібнішають, період цвітіння звузиться, а довготривалість життя, якщо дивитись в перспективу, значно скоротиться. Окрім цього, такі рослини, досягнувши 25-30-річного віку, стануть і фізично нестійкими: через обважнілу від листків, суцвіть, вологи або снігу крону нахиляються, а деякі крайні в групі, будучи однобокими, зваляться на грунт. Щоб запобігти цьому явищу, оптимальною відстанню між кущоподібними рослинами має бути 4-5(6) м, а між штамбовими - 3$4(4,5)$ м. Такі метричні рамки зумовлені агрофоном ділянки: чим він сприятливіший для рослин, тим більша відстань між ними має бути. У своїй роботі, для найправильнішого визначення відстані між бузками, виміряємо діаметр крони кількох багаторічних рослини цього виду, що ростуть неподалік в аналогічних умовах. Його розмір буде відстанню між рослинами в групі.

Якщо під час створення Саду бузків його рослини розмістили надто густо, потрібно в період змикання їхніх крон відсадити або видалити зайві, аби вчасно збільшити життєвий простір залишеним. Проте часто буває так, що цю операцію своєчасно не виконали й навіть 25-35-річні рослини, через їхнє загущення, стали кволими, а деякі - нежиттєздатними. Для відновлення декоративності ділянки бузків можна скористатися трьома варіантами. Перший - надто кардинальний: замінити всі рослини на молоді, розташувавши одну від одної на оптимальній відстані. Проте цей варіант може бути неприйнятним через те, що саме ця група бузку є важливою складовою частиною якоїсь паркової композиції, яку не варто порушувати. Тому другим варіантом має стати видалення всіх найслабкіших кущів, що відразу значно покращить освітленість тих, які залишились. Одночасно для останніх збільшиться й площа для кореневого живлення. Наступним етапом має стати прорідження крони, яким вдасться наблизити ії до кореневої системи, що забезпечить рослині фізичну стійкість та активізує в ній функціональний коренево-листковий зв'язок [3]. Здійснити цей захід треба як можна раніше в часовому вимірі, бо окрім згаданого, вони раніше чи пізніше почнуть страждати й від хвороб: щонайперше від борошнистої роси.

Третій варіант може стати продовженням другого варіанта. Ним завбачуємо поступову заміну старих, найменш декоративних на молоді (4-5-річні) рослини. При цьому грунт, втомлений багаторічним беззмінним культивуванням старих бузків, треба удобрити або хоча б частково замінити на родючий. Місце садіння має бути гарно освітленим. Така уповільнена реконструкція може зайняти 4-5 років, але за правильного підходу до неї, буде малопомітною.

Омолоджувати ж рослини S. vulgaris можна двома методами. К. Брикелл [1] рекомендує зрізати рано весною тонкі гілки на рівні грунту, а товсті - на висоті 30 см від нього. Унаслідок цього сплячі бруньки на таких фрагментах стовбурів проростуть й утворять до кінця вегетаційного періоду довгі, різні за висотою пагони. На другий рік автор рекомендує видалити більшість 3 них, залишивши по 2-3 найбільш потужних на кожному укороченому стовбурові. В наступні роки 3 цих пагонів він пропонує сформувати крону.

Наш досвід омолодження рослин $S$. vulgaris свідчить про неприйнятність цього способу, особливо в умовах родючих українських грунтів. На це є кілька причин. Перша полягає в тому, що саме на таких грунтах після використання рекомендованого К. Брикелл способу, виростуть надто довгі, часто фасційовані пагони з віялоподібно розгалуженою вершиною. Пластинка їхніх листків буде в 2-3 рази більшою за площею, аніж у звичайних. За першого рясного дощу з вітром більшість таких пагонів легко відвалиться від стовбура. Відбувається це навіть тоді, коли ці пагони підв'язані до кілочка. Першопричиною потужного росту їх $є$ інтенсивне кореневе живлення, яке було "розраховане" на сотні, навіть тисячі, активних бруньок усієї крони, а звелося до забезпечення тільки декількох сплячих бруньок омолодженої за цим методом рослини.

Друга причина зводиться до того, що такий спосіб провокує появу великої кількості порості підщепи (насамперед - від столонів), з якою треба буде постійно боротись, аби вона не послаблювала фізіологічний стан прищепи з найгіршими для неї наслідками.

Третя причина неприйняття цього способу зумовлена нанесенням стовбурам багатосантиметрових зрізів, які, як вже було зазначено, в $S$. vulgaris ніколи не зможуть загояться. Процес руйнування деревини цих ран може мати різну активність, але через 10-15 років вона, навіть за неодноразового нанесення на неї садового вару, струхліє до центрального кореня. Така кущова рослина за першого перевантаження крони вологими суцвіттями чи снігом, розвалиться при своїй основі на окремі фрагменти. Відновити іiі, якщо це була щепа - неможливо, адже вся порість, з якої можна було б сформувати новий кущ, утвориться зі столонів підщепи. Якщо ж це була власнокоренева рослина сорту, відновити іiї вдасться за рахунок потужної порості столонів. Для цього спочатку треба якнайнижче спиляти старий стовбур. Цим заходом унеможливимо появу пристовбурної порості, яка, досягнувши 1,5-2,0-метрової висоти, з часом відчахнеться від окоренка. Далі з порості столонів сформуємо багато- чи одностовбурну рослину.

Надто інтенсивне омолодження крони, запропоноване К. Брикелл, непомірно порушує й фізіологічний зв'язок між надземною й підземною частинами рослини. Спочатку це призводить до різкого затухання фотосинтезу (крона практично відсутня), а потім, корелятивно, - i до уповільнення ризосинтезу: через мізерне надходження асимілятів до кореневої системи. Отже, різке послаблення функціонального корелятивного кореневолисткового зв'язку, яке виникає при цьому, зумовить 
відповідно й значне зменшення фізичного обсягу підземної частини рослини, повністю відновити який, навіть за оптимального багаторічного агротехнічного догляду за нею, вже не вдасться. Але саме таке, надто кардинальне, втручання в рослинний організм за згаданим методом, неминуче призведе до передчасного старіння, а потім і до поступового його відмирання [3]. Щоправда, проявиться це тільки з часом, адже в перші роки новосформована таким методом крона виглядатиме декоративніше, аніж вона була до цього. Безперечно, що без цього заходу деякі надто ослаблі загущеною посадкою рослини приречені на відмирання. Через це всі згадані наслідки неправильного розміщення рослин в монокультурному Саду бузків треба передбачити ще під час його створення.

Враховуючи зазначене вище, омолоджувати багаторічні рослини S. vulgaris варто не таким дошкульним для них способом, який запропонував К. Брикелл. Тобто за один прийом знижувати крону треба тільки на третину, або на половину іiї висоти, залучаючи для цього переважно 4-5-річні, а іноді й дещо молодші гілки. Вирізати на кільце їх не варто: треба тільки вкоротити. За такої схеми у кроні залишиться велика кількість активних і сплячих бруньок, з яких виросте багато пагонів, що й попередить їхній бурхливий і затяжний, іноді до осені, ріст. При цьому функціональний корелятивний коренево-листковий зв'язок не зазнає значних порушень.

У разі вкорочування гілок треба враховувати, що більшість нових пагонів проросте поблизу місця зрізу. Їхній ріст завжди є досить активним, одначе сповільнити його можна завдяки збереженню (іноді тимчасовому) гілок, які розташовані нижче від місця укорочення скелетної гілки.

Омолоджені за таким методом рослини бузку квітуватимуть вже в перший рік після здійснення цього заходу. Суцвіть буде менше, але за розмірами вони значно переважатимуть попередні й матимуть чітко виражені морфометричні ознаки сорту.

Отже, знижуючи крону за рахунок гілок вищих порядків та дрібних, явно ослаблих, не нанесемо рослині значних ран. При цьому стовбури й скелетні гілки першого порядку взагалі їх не матимуть, тому надовго залишатимуться в фітопатологічно здоровому стані. За агрономічно правильного догляду за пристовбурним грунтом і кроною, декоративність таких рослин буде відновлена впродовж двох років.

Особливо негативно реагують на надто інтенсивне обрізування густопосаджені штамбові рослини $S$. vulgaris. Спричинюється це тим, що на їхньому єдиному стовбурові, а також на скелетних гілках першого порядку, за багаторічного догляду за ним (систематичне видалення пагонів-вовчків), дуже мало залишилось сплячих бруньок або вони згруповані тільки в кількох місцях. Через це їхня крона якщо й відновиться після такого омолодження, то тільки частково й асиметрично. У цьому ми переконалися на власному досвіді, коли в 1977 р. були змушені інтенсивно омолодити порівняно молоді, 29-річні штамбові рослини сортів $S$. vulgaris, які розмістили надто густо (через 0,9-1,5 м) ще під час створення в 1948 р. Сирингарію НБС. Через згадану причину їхня крона якщо й відновилась, то частково: за рахунок надто довгих пагонів, які поодиноко або групами були асиметрично розкидані як на стовбурові, так i на скелетних гілках першого порядку. До середини літа вони досягали 1,0-1,5-метрової висоти, а тому легко відвалювались навіть від незначного вітру. Як наслідоквся ділянка 3 цими рослинами набула непривабливого вигляду, що змусило радикально іiі реконструювати: всі рослини викорчувати, коріння ретельно вибрати, внести органічні добрива і в 1978 р. посадити молоді рослини.

Отже, як і у випадку з кущовими, штамбові рослини треба обрізати за рахунок гілок вищих порядків, що попередить появу великих ран і бурхливий ріст пагонів поблизу місця зрізу.

Загалом же вдаватись до інтенсивного омолодження рослин бузку потреби не буде, якщо ростимуть вони в колекції вільно, на оптимальному для них агрофоні й гарному освітленні. Це треба враховувати ще на стадії проектування Сирингарію, що посприяє його рослинам досягти високої декоративності й довговічності.

\section{Висновки}

Для того, щоб рослин $S$. vulgaris були високодекоративними й довговічними, треба:

a) сформувати крону в 2-3-річному віці;

б) систематично виконувати обрізування крони, до якого спонукає дихотомічне гілкування. При цьому варто видаляти тільки невеликі пригнічені та зайві гілки найвищих порядків;

в) залучати для інтенсивного проріджування крони (якщо виникла нагальна потреба) скелетні гілки тільки 4-го і вищих порядків. Скелетні гілки 1-го порядку, аби не заподіяти стовбурам великих ран, видаляти не варто;

2) уникати кардинального омолодження рослин методом низького зрізування стовбурів на висоті кількох десятків сантиметрів від їхньої основи, оскільки цей метод тільки тимчасово покращує декоративність, але надто вкорочує їм довговічність. На останню найбільш негативно діють великі рани й надто порушений функціональний корелятивний коренево-листковий зв'язок у рослинному організмові.

\section{References}

1. Brikell, K. (1987). Obrezka rastenii. Moscow: Publishing Mir, 197 p. [In Russian].

2. Gormov, A. N. (1963). Siren. Moscow: Publishing Moskovskiy rabochiy, 247 p. [In Russian].

3. Kazarian, V. O. (1969). Starenie vysshikh rastenii. Moscow: Publishing Nauka, 312 p. [In Russian].

4. Rubtcov, L. I., Mikhailov, N. L., \& Zhogoleva, V. G. (1980). Vidy $i$ sorta sireni, kultiviruemye v SSSR. Kiev: Publishing Nauka, 126 p. [In Russian].

V. K. Gorb, Yu. O. Klymenko, N. I. Dovhaliuk

M. M. Gryshko National Botanical Garden, NAS Ukraine, Kyiv, Ukraine

\section{INFLUENCE OF THE CROWN CARE SYSTEM ON THE DECORATIVENESS AND LONGEVITY OF PLANTS OF SYRINGA VULGARIS L. VARIETIES}

The plants of Syringa vulgaris L. within the culture are proved to require annual pruning of the crown. It is caused by dichotomous (not real) branching, according to which each annual branch produces two shoots in the spring from the apical pair of buds and a few more from the buds located below the axis of this branch. Therefore, their total number at least triples every year. The root 
system will not be able to increase its mass and physiological activity in such volumes during this time, which correlatively causes a significant reduction in the size of shoots and inflorescences. If care was irregular or absent, there would be a need for intensive thinning or radical rejuvenation of the crown. These measures are found to able to improve the decorativeness of plants, but they will negatively affect longevity. There are two reasons for this. The first is the appearance of various sections on the trunk or on skeletal branches after removal of the branches on the ring. We have defined that even among these sections, even $1.5-2.0 \mathrm{~cm}$ ones will never heal, but in 10-15 years, their wood will turn into dust. The wood of large wounds is destroyed faster, which causes the formation of hollows and the slow death of the whole plant. The second reason for the shortening of longevity is a sudden distortion of the functional correlative root-leaf connection, which is a consequence of a sharp decrease in the rejuvenated plant aboveground part. Firstly, this leads to a rapid attenuation of photosynthesis (the crown is almost absent), and then, consequently, to slowing of root synthesis due to the scant supply of assimilates to the roots. As a result, the mass of the physiologically active part of the root system will be significantly reduced, which will negatively affect the longevity of the plant as a whole. It has also been established that thickened planting of lilacs also forces intensive pruning of the crown. To restore its decorativeness, all oppressed plants should be removed, and the rest should be lowered by one third to bring it closer to the root system, which will provide the plants with physical resistance and activate their root-leaf connection. This measure should be carried out as early as possible in time, because weak plants will begin to suffer from diseases. The branches should be shortened, not cut into a ring, in order not to injure the trunk. It is emphasized that with the optimal location of plants in groups, the need for intensive rejuvenation is eliminated as the annual removal of small, shaded, and low-ornamental branches will suffice. With this approach to the formation and pruning of the crown, lilacs will be decorative and in most cases - durable.

Keywords: Syringa vulgaris L.; crown formation; decorativeness; durability. 